Article

\title{
Bioregulators Can Improve Biomass Production, Photosynthetic Efficiency, and Ornamental Quality of Gazania rigens L.
}

\author{
Faisal Zulfiqar ${ }^{1, *(\mathbb{D}}$, Adnan Younis ${ }^{1}$, Zainul Abideen ${ }^{2}{ }^{\oplus}$, Alessandra Francini ${ }^{3}$ and \\ Antonio Ferrante 4 (D) \\ 1 Institute of Horticultural Sciences, Faculty of Agriculture, University of Agriculture Faisalabad, \\ Faisalabad 38040, Pakistan; adnanyounis@uaf.edu.pk \\ 2 Institute of Sustainable Halophyte Utilization, University of Karachi, Karachi 75270, Pakistan; \\ Zuabideen@uok.edu.pk \\ 3 Institute of Life Science, Scuola Superiore Sant'Anna, Piazza Martiri della Libertà 33, I-56127 Pisa, Italy; \\ a.francini@santannapisa.it \\ 4 Department of Agricultural and Environmental Sciences, Università degli Studi di Milano, via Celoria 2, \\ 20133 Milano, Italy; antonio.ferrante@unimi.it \\ * Correspondence: ch.faisal.zulfiqar@gmail.com; Tel.: +92-344-721-6320
}

Received: 30 August 2019; Accepted: 12 November 2019; Published: 19 November 2019

\begin{abstract}
Gazania rigens L. is a perennial herbaceous plant that belongs to the Asteraceae family, widely used as bedding or ornamental potted plants. The environmental and economic sustainability of ornamental production can be enhanced using environmentally friendly bioregulators. A pot experiment was conducted to evaluate the influence of key bioregulators gibberellic acid $\left(\left(\mathrm{GA}_{3}\right)\right.$ at 50 , 100 or $\left.150 \mathrm{mg} \mathrm{L}^{-1}\right)$, humic acid ((HA) at 100, 300 or $\left.600 \mathrm{mg} \mathrm{L}^{-1}\right)$, and ascorbic acid ((AA) at 50, 100 or $\left.200 \mathrm{mg} \mathrm{L}^{-1}\right)$ ), on the growth, leaf gas exchange, and ornamental quality of $G$. rigens. The results indicated that plants treated with foliar applications of $\mathrm{GA}_{3}, \mathrm{HA}$, or AA exhibited higher plant fresh and dry biomass, plant height, leaf area, and leaf area ratio, root-shoot ratio, root-shoot mass fractions, and number of flowers, as well as the flowers display time. All bioregulator treatments enhanced the vegetative and floral characteristics of Gazania plants. The $\mathrm{GA}_{3}$ was the most efficient at the concentration of $100 \mathrm{mg} \mathrm{L}^{-1}$. The highest efficacy of HA and AA treatments was observed at the higher concentrations, 600 and $200 \mathrm{mg} \mathrm{L}^{-1}$, respectively. These results were associated with higher photosynthetic rate (A), transpiration rate (E) as well as stomatal conductance (gs), and water use efficiency (WUE). In conclusion, the results suggest that foliar-applied bioregulators to Gazania are promising and represent sustainable strategies to enhance growth, flowering, and flower display time of Gazania plants.
\end{abstract}

Keywords: gazania; gas exchange parameters; flowering; ornamental plants; root mass fraction

\section{Introduction}

Gazania (Gazania rigens L.) is a popular perennial herbaceous plant native to Southern Africa, frequently cultivated as an annual potted flower or garden plant around the world, for its high ornamental value. The use of inorganic fertilizers and synthetic chemicals in the horticulture sector is necessary for adequate productivity, but often the high quantities used may have negative effects on the environment and human health [1]. Ornamental plant production includes the cultivation of cut-flower crops, potted plants, gardening plants, and landscaping planning [2-4]. Ornamental plant cultivation has been increasing in recent years [2]. The use of bioregulators may lower the environmental impact of ornamental crop production $[5,6]$. These products can have great potential practical applications 
for improving plant growth and development. Bioregulators and natural biostimulants are widely used in agriculture and horticulture systems to enhance vegetative growth, flowering, yield, harvest quality, and modification of plant constituents [1,7]. The effectiveness of different chemicals varies under different growth conditions, as well as among plant species. There are various chemicals used for plant growth improvement due to their consistent effects on photosynthesis [8]. Bioregulators include hormones or other compounds/substances with hormone-like activities, inorganic, and organic elements that are able to enhance plant growth and development, and flower and bulblet production.

Gibberellic acid $\left(\mathrm{GA}_{3}\right)$ is a natural phytohormone that has promising applications in agriculture and in the horticulture industry due to its positive impact on plant growth and development [9]. $\mathrm{GA}_{3}$ has been used as a plant growth regulator in different crops, ornamental plants, and orchards, exhibiting positive impacts for enhancing seed germination [10,11], flowering [12,13], endosperm mobility, leaf expansion, leaf development, shortening of juvenile phase, stem elongation, floral transitioning, and setting of flowers and fruits $[14,15]$. Foliar applications of $\mathrm{GA}_{3}$ enhance the flower stem length in cut-flowers grown in soil [16]. In calla lily, $\mathrm{GA}_{3}$ treatments increased the number of flowers and shortened the flowering time (earlier flower production). The $\mathrm{GA}_{3}$ is also used as a leaf yellowing inhibitor and used as a postharvest or post-production treatment in many ornamental species [17-19].

Humic acids (HA) are a type of organic fertilizer that act as a precursor of humic compounds [20]. The application of HA improved plant health and increased yield by improving the soil structure, as well as facilitating the macro- and micro-nutrients uptake and assimilation. The HA enhanced photosynthesis, nitrogen assimilation, and secondary metabolism in plants [21-23]. It enhanced rooting in micro-propagation [24]. It has been demonstrated that HA stimulated root growth and development by increasing root cell elongation and cell expansion, and induced the formation of lateral roots [25]. In addition, different concentrations of HA have a significant effect on plant metabolism and plant physiology [26]. Soppelsa et al. [27] showed that HA improved apple fruit quality in comparison to different bioregulators. Combined applications of HA and plant growth-promoting bacteria enhanced the yield and quality of organic tomatoes [28]. In a meta-analysis, Rose et al. [29] described the exogenous application of HA increased $(22 \%)$ root and shoot dry weight in different plant species.

Ascorbic acid (AA) also known as Vitamin $C$ is a water-soluble vitamin and a ubiquitous metabolite that is involved in a variety of key functions in plant tissues. AA plays an important role in the biosynthesis of various plant hormones, essential organic acids, and takes part in numerous biological processes such as xanthophylls metabolism [30]. Recent studies suggest that AA is also involved in the regulation of plant cell division and elongation [31]. Akram et al. [32] stated that AA is involved in many vital functions as photo-protection, antioxidant defense, and regulation of growth and photosynthesis process.

The effect of AA, HA, and $\mathrm{GA}_{3}$ applications on the Gazania plants has not been investigated yet and their applications might have a positive effect on the production and quality of ornamental plants. The hypothesis of this work was to improve the growth and flowering of Gazania using plant bioregulators. Therefore, this study compared the effects of three chemicals with the regulation ability of biological processes such as growth, leaf gas exchange, and several ornamental quality parameters of Gazania plants.

\section{Materials and Methods}

\subsection{Plant Materials}

A pot experiment was conducted in 2017-2018 (October to May) at the floriculture experimental area of the Institute of Horticultural Sciences, University of Agriculture Faisalabad, Pakistan using Gazania (Gazania rigens L.) cv. New Day ${ }^{\circledR}$ Bronze Shades (PanAmerican seed, West Chicago, Illinois USA). Seeds were surface sterilized (4.0\% sodium hypochlorite solution) for $10 \mathrm{~min}$ at room temperature followed by triple-rinsing with distilled sterile water. On 12 October, Gazania seeds were sown in a glass house in plastic seedling propagation trays ( 72 cells per tray) placing one seed in each planting cell filled 
with soilless growing media (peat/perlite $80 / 20 v / v$ ). In the glasshouse, average daytime temperature ranged from 24 to $26^{\circ} \mathrm{C}$, while night temperature ranged from 16 to $18^{\circ} \mathrm{C}$. On 23 November, (healthy grown and with third pair of leaves) into plastic pots $(18 \mathrm{~cm}$ diameter and $15 \mathrm{~cm}$ depth) and the growing substrate was a mixture of brown peat and perlite 80/20 (v/v). Fertilization was performed using Hoagland's solution (without $\mathrm{KH}_{2} \mathrm{PO}_{4}$ ) at 14-day intervals and watering was carried out on the basis of plant requirements (4 days interval), keeping the plants in the optimal range.

\subsection{Experiment Design, Chemicals Application, and Crop Management}

The experiment was established in a randomized complete block design with 10 treatments and 15 plants per treatment with a total of 150 plants. Plants were sprayed with a hand sprayer in the morning to the point of runoff from leaves (upper portion) on 8 December with gibberellic acid $\left(\mathrm{GA}_{3}\right.$, Sigma-Aldrich Corp., St. Louis, MO, USA) (50, 100, and $150 \mathrm{mg} \mathrm{L}^{-1}$ ), humic acid (HA, Sigma-Aldrich Corp., St. Louis, MO, USA) (100, 300, and $600 \mathrm{mg} \mathrm{L}^{-1}$ ) and ascorbic acid (AA, Sigma-Aldrich Corp., St. Louis, MO, USA) (50, 100, and $\left.200 \mathrm{mg} \mathrm{L}^{-1}\right)$, along with the distilled water treatment as the control. Two weeks later, the second application of treatments was repeated. Plants were grown under standard agro-technical procedures including fertilizer rates, weeding, irrigation, and pest management according to plant needs.

\subsection{Morphological Parameters and Ornamental Attributes}

Plants were uprooted carefully 8 weeks after transplanting and the growing substrate was gently washed from the roots. Plants were divided into shoots, leaves, roots, and flowers. 10 plants per treatment were harvested and their height $(\mathrm{cm})$, flower shoot length $(\mathrm{cm})$, flower diameter $(\mathrm{cm})$ were measured. Flower stalk/shoot diameter $(\mathrm{mm})$ was measured using a Vernier caliper. The numbers of leaves and number of flowers per plant were counted. Flower display time was counted by number of days from flower opening to wilting. Leaf area per plant $\left(\mathrm{cm}^{2}\right)$ was determined using a leaf area meter (LICOR-3000C Portable leaf area meter) and leaf area ratio $\left(\mathrm{cm}^{2} \mathrm{~g}^{-1}\right)$ was determined by dividing the total leaf area of a plant by the dry mass of the entire plant. Ten shoot and root samples were weighed for fresh weight determination and then these samples were oven-dried at $70{ }^{\circ} \mathrm{C}$ until they reached a constant dry. Shoot and root mass fraction were measured by dividing the shoot and root fresh mass by plant mass. Root and shoot fresh mass ratios were determined. The moisture percentage was measured from the fresh and dry mass of the whole plant or shoot and root.

\subsection{Leaf Gas Exchange Measurements}

At the onset of flowering stage, leaf gas exchanges (the net photosynthetic rate (A), transpiration rate (E), and stomatal conductance (gs)) were recorded on 2 fully expanded leaves (random middle leaves) per plant and a total of 10 plants per treatment by the LCi gas exchange portable equipment (ADC BioScientific Ltd, Hoddesdon, UK) at $10 \mathrm{a} . \mathrm{m}$. irradiance just close to $1200 \mu \mathrm{mol} / \mathrm{m}^{2} / \mathrm{s}$. Leaf temperature was $25+5^{\circ} \mathrm{C}$. From these parameters, water use efficiency (WUE) was also calculated as $\mathrm{WUE}=\mathrm{A} / \mathrm{Gs} \times 1000(\mu \mathrm{mol} / \mathrm{mmol})$.

\subsection{Statistical Analysis}

For each randomized block (three blocks in total), 5 plants per treatment were used (total 15 plants per treatment). Experimental data were subjected to the D'Agostino\&Pearson and Shapiro-Wilk normality tests. Since the data were not normally distributed, the statistical analysis was performed using non-parametric tests such as the Kruskal-Wallis test (Graphpad, Prism, USA). Sample means and significant differences among means $(P \leq 0.05)$ were compared using Dunn's multiple comparisons test. 


\section{Results}

\subsection{Plant Growth and Morpho-Agronomic Parameters}

The morpho-agronomic traits monitored revealed that treatments positively influenced plant growth. The $\mathrm{GA}_{3}$ was the most active in stimulating the plant development and the most effective concentration was $100 \mathrm{mg} \mathrm{L}^{-1}$, even if no significant differences were found among the $\mathrm{GA}_{3}$ concentrations The HA and AA had a dose-response effect on plant height. After the $\mathrm{GA}_{3}$, the most efficient treatments were the AA at $200 \mathrm{mg} \mathrm{L}^{-1}$ and the HA $600 \mathrm{mg} \mathrm{L}^{-1}$. The plant height was higher in the $\mathrm{GA}_{3}$ treatments compared to the control and other treatments. On average, the plant height in the $\mathrm{GA}_{3}$ treatments was $25 \mathrm{~cm}$ (Figure 1A). Control plants did not grow past $10 \mathrm{~cm}$ of height. The plant height of HA treated plants ranged from 12.5 to $19 \mathrm{~cm}$, while in the AA treatments the plant height was comprised from 12.5 to $21 \mathrm{~cm}$.

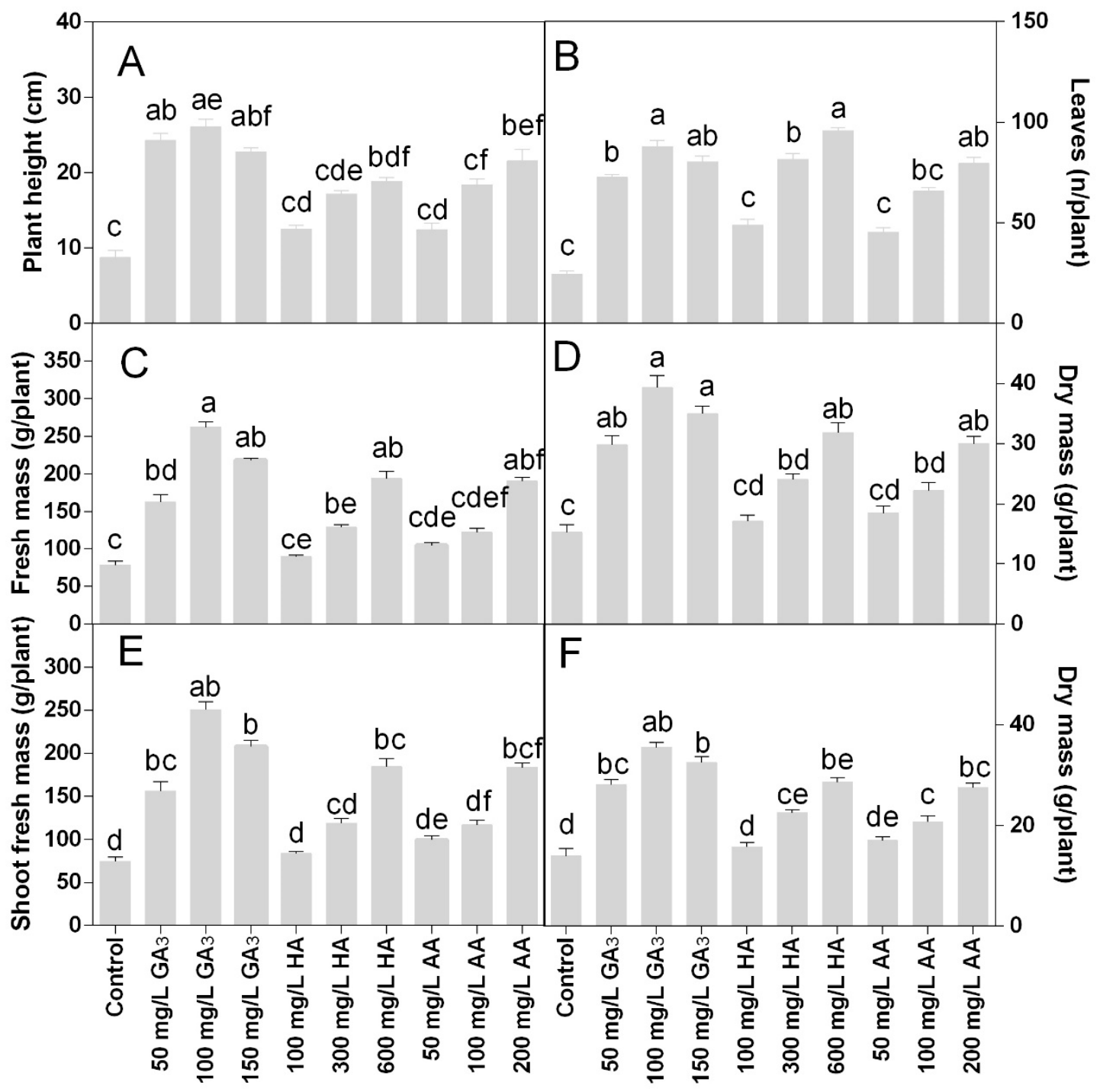

Figure 1. Effect of gibberellic acid (50-100-150 mg L ${ }^{-1}$ GA), humic acid (100-300-600 $\mathrm{mg} \mathrm{L}^{-1} \mathrm{HA}$ ), and ascorbic acid (50-100-200 $\mathrm{mg} \mathrm{L}^{-1}$ AA) foliar applications on the Gazania (A) plant height; (B) number of leaves; (C) plant fresh mass; (D) plant dry mass; (E) shoot fresh mass; (F) shoot dry mass. Values are means \pm SD $(n=15)$. Data were subjected to the Kruskal-Wallis test. Differences among means were determined using Dunn's multiple comparisons test. Significant differences $(P<0.05)$ among bioregulators foliar treatments are indicated by different letters. 
The number of leaves per plant was 2-4-fold higher in the treatments than the control. The highest leaf number was found in the treatment with $600 \mathrm{mg} \mathrm{L}^{-1} \mathrm{HA}$ (Figure 1B), even if there were no statistical differences compared to 100 or $150 \mathrm{mg} \mathrm{L}^{-1} \mathrm{GA}_{3}$ or $200 \mathrm{mg} \mathrm{L}^{-1} \mathrm{AA}$. The fresh and dry mass of plants followed the same trend of the plant heights in all treatments.

The leaf area was significantly increased in all treatments. Statistical analysis showed that leaf area and leaf area ratio data were significantly different for $P<0.05$. The highest values were induced by the $\mathrm{GA}_{3}$ treatments, along with $600 \mathrm{mg} \mathrm{L}^{-1} \mathrm{HA}$ and $200 \mathrm{mg} \mathrm{L}^{-1}$ AA. The highest leaf area was observed in $100 \mathrm{mg} \mathrm{L}^{-1} \mathrm{GA}_{3}$ with $50 \mathrm{~cm}^{2}$, which was almost double the control (Figure 2A). The higher concentrations of HA and AA showed a leaf area similar (no statistical differences) to the $50 \mathrm{mg} \mathrm{L}^{-1}$ $\mathrm{GA}_{3}$ that was $42 \mathrm{~cm}^{2}$ on average. The leaf area ratio was also significantly affected by the treatments (Figure 2B). The lowest values were found at the highest doses of the three treatments.

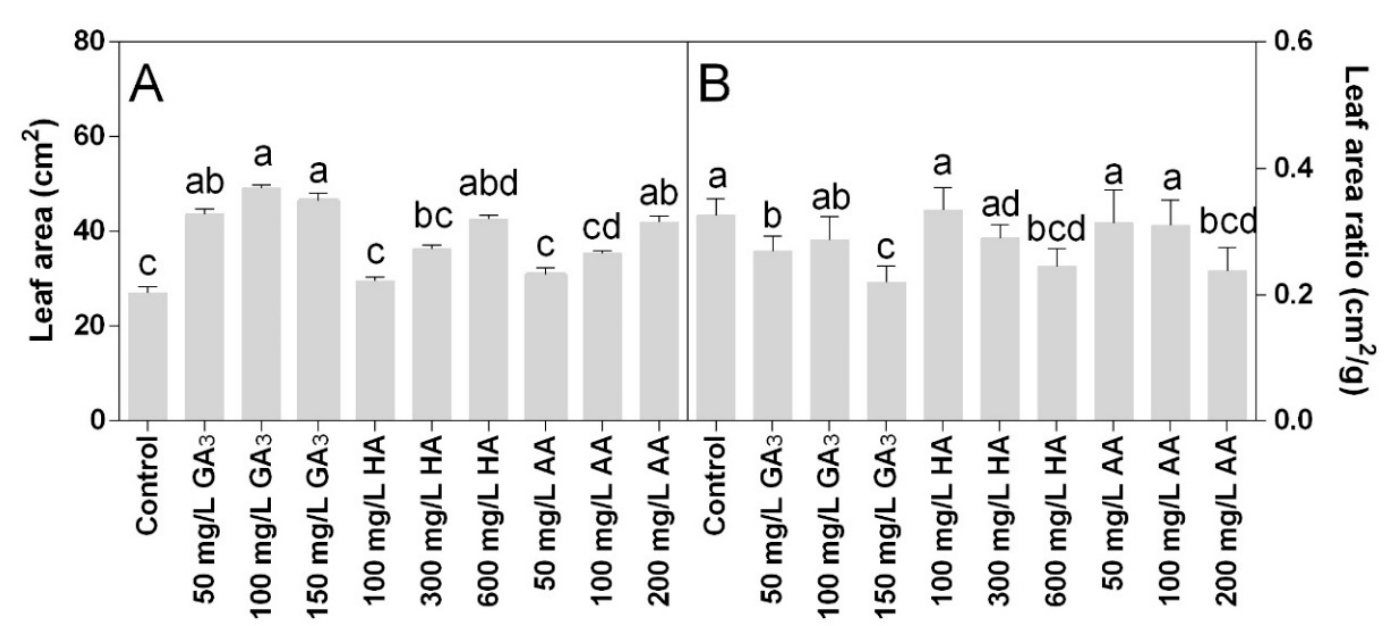

Figure 2. Effect of gibberellic acid (50-100-150 $\left.\mathrm{mg} \mathrm{L}^{-1} \mathrm{GA}\right)$, humic acid (100-300-600 $\mathrm{mg} \mathrm{L}^{-1} \mathrm{HA}$ ), and ascorbic acid (50-100-200 $\mathrm{mg} \mathrm{L}^{-1}$ AA) foliar applications on the Gazania (A) leaf area and (B) leaf area ratio. Values are means $\pm \mathrm{SD}(n=15)$. Data were subjected to the Kruskal-Wallis test. Differences among means were determined using Dunn's multiple comparisons test. Significant differences $(P<0.05)$ among bioregulators foliar treatments are indicated by different letters.

Statistical analysis showed that fresh and dry root biomass data were significantly different for $P<0.05$. The fresh roots biomass increased in all treated plants (Figure 3A), confirming the effects observed for the areal part of the plants. The HA and AA showed dose-response results. The highest root fresh biomass was found in the treatment HA $600 \mathrm{mg} \mathrm{L}^{-1}$, followed by $100 \mathrm{mg} \mathrm{L}^{-1} \mathrm{GA}_{3}$ and $200 \mathrm{mg} \mathrm{L}^{-1} \mathrm{AA}$, which showed no statistically different to $150 \mathrm{mg} \mathrm{L}^{-1} \mathrm{GA}_{3}$ or $300 \mathrm{mg} \mathrm{L}^{-1} \mathrm{HA}$. The AA treatments were less effective, where the highest dose of $200 \mathrm{mg} \mathrm{L}^{-1}$ was not statistically different to $150 \mathrm{mg} \mathrm{L}^{-1} \mathrm{GA}_{3}, 300 \mathrm{mg} \mathrm{L}^{-1} \mathrm{HA}$, or $100 \mathrm{mg} \mathrm{L}^{-1} \mathrm{AA}$. Similar trends with slight differences were observed for the roots dry mass. 


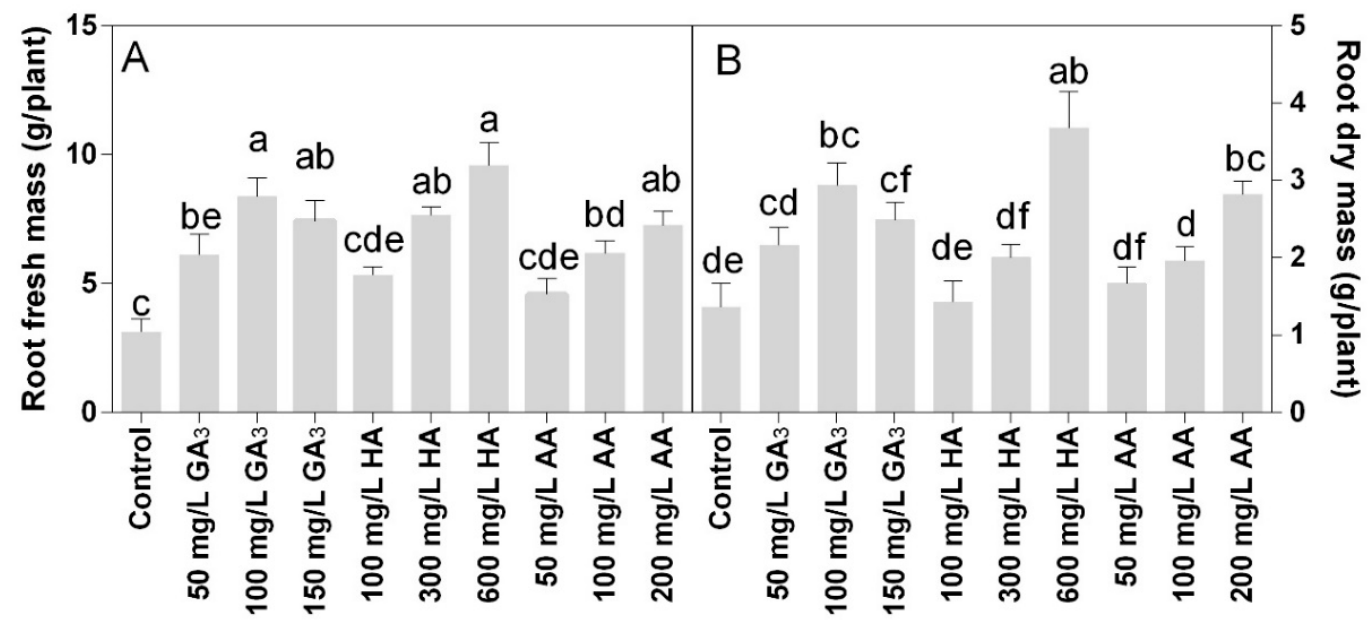

Figure 3. Effect of gibberellic acid (50-100-150 $\left.\mathrm{mg} \mathrm{L}^{-1} \mathrm{GA}\right)$, humic acid (100-300-600 mg L $\mathrm{m}^{-1} \mathrm{HA}$ ), and ascorbic acid (50-100-200 $\mathrm{mg} \mathrm{L}^{-1}$ AA) foliar applications on the Gazania (A) root fresh mass and $(B)$ root dry mass. Values are means \pm SD $(n=15)$. Data were subjected to the Kruskal-Wallis test. Differences among means were determined using Dunn's multiple comparisons test. Significant differences $(P<0.05)$ among bioregulators foliar treatments are indicated by different letters.

Shoot mass fraction was only significantly higher in $100 \mathrm{mg} \mathrm{L}^{-1} \mathrm{GA}_{3}$ treatment compared to the control (Figure 4A). The root mass fraction and the root-shoot ratio were lower at the higher doses of $\mathrm{GA}_{3}$ treatments or $200 \mathrm{mg} \mathrm{L}^{-1} \mathrm{AA}$ compared to the other treatments (Figure $4 \mathrm{~B}, \mathrm{C}$ ). The highest values were found in the 100 and $300 \mathrm{mg} \mathrm{L}^{-1} \mathrm{HA}$.

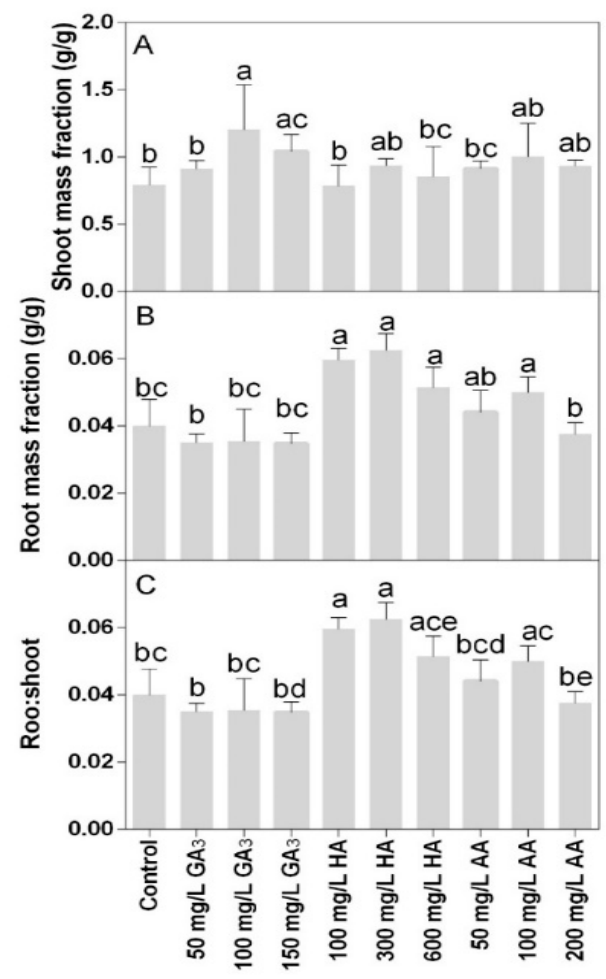

Figure 4. Effect of gibberellic acid (50-100-150 $\mathrm{mg} \mathrm{L}^{-1} \mathrm{GA}$ ), humic acid (100-300-600 $\mathrm{mg} \mathrm{L}^{-1} \mathrm{HA}$ ), and ascorbic acid (50-100-200 $\mathrm{mg} \mathrm{L}^{-1} \mathrm{AA}$ ) foliar applications on the Gazania (A) shoot mass fraction and (B) root mass fraction (C) root-shoot ratio. Values are means $\pm \mathrm{SD}(n=15)$. Data were subjected to the Kruskal-Wallis test. Differences among means were determined using Dunn's multiple comparisons test. Significant differences $(P<0.05)$ among bioregulators foliar treatments are indicated by different letters. 
The flower production was positively affected by the treatments. All the treatments induced higher flower production than control (Figure 5A). The highest value was observed in $200 \mathrm{mg} \mathrm{L}^{-1}$ AA, with the flower number per plant above 40 . The treatment with $100 \mathrm{mg} \mathrm{L}^{-1}$ also increased the number of flowers per plant, about 4-fold higher than control. Plants treated with $100 \mathrm{mg} \mathrm{L}^{-1} \mathrm{HA}$ or AA produced double flowers compared with control, but lower than other treatments.

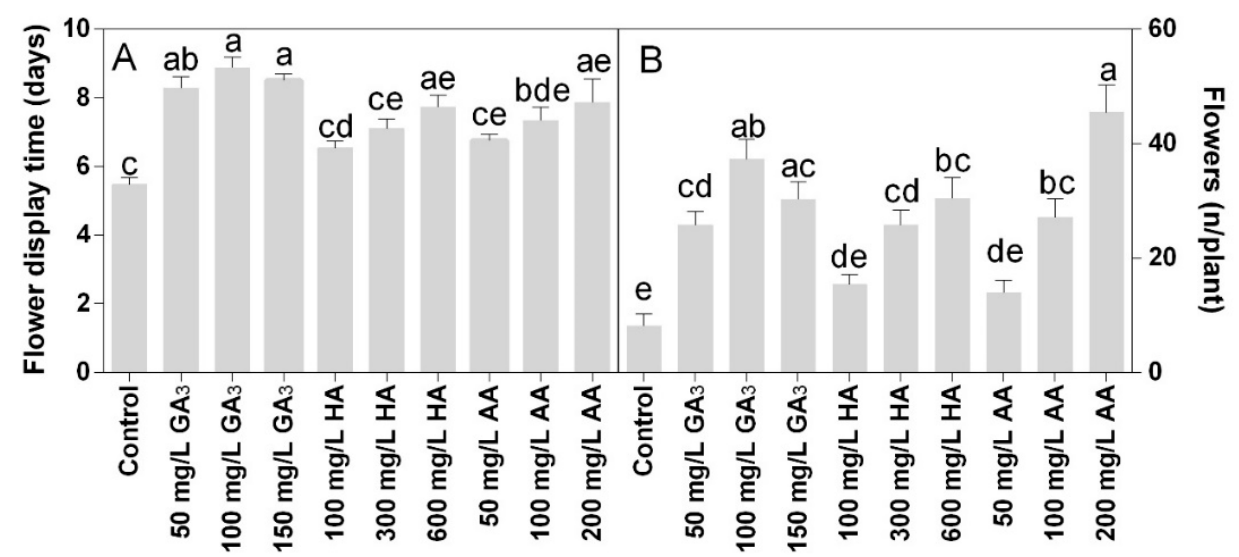

Figure 5. Effect of gibberellic acid (50-100-150 $\mathrm{mg} \mathrm{L}^{-1} \mathrm{GA}_{3}$ ), humic acid (100-300-600 $\mathrm{mg} \mathrm{L}^{-1} \mathrm{HA}$ ), and ascorbic acid (50-100-200 $\mathrm{mg} \mathrm{L}^{-1} \mathrm{AA}$ ) foliar applications on the Gazania (A) number of flowers per plant and (B) flowers display time. Values are means $\pm \operatorname{SD}(n=15)$. Data were subjected to the Kruskal-Wallis test. Differences among means were determined using Dunn's multiple comparisons test. Significant differences $(P<0.05)$ among bioregulators foliar treatments are indicated by different letters.

Flower life was also significantly higher in all treatments compared to the control. The most effective treatments were 100 or $150 \mathrm{mg} \mathrm{L}^{-1} \mathrm{GA}_{3}$, within 8.5-9 days of the flower's life (Figure 5B). The HA or AA treatments showed similar values, from the lowest to the highest concentration.

Flower morphology was significantly enhanced by the treatments showing a positive effect on the flower head (Figure 6A) and shoot diameter (Figure 6C). The highest values of flower head diameter were observed at 100 or $150 \mathrm{mg} \mathrm{L}^{-1} \mathrm{GA}_{3}$ treatments. The $600 \mathrm{mg} \mathrm{L}^{-1} \mathrm{HA}$ or $200 \mathrm{mg} \mathrm{L}^{-1} \mathrm{AA}$ treatments showed results similar to $50 \mathrm{mg} \mathrm{L}^{-1} \mathrm{GA}_{3}$. Wider variations were found in the flower shoot length among treatments. For this parameter, the highest value was observed in the $100 \mathrm{mg} \mathrm{L}^{-1} \mathrm{GA}_{3}$. The 50 or $150 \mathrm{mg} \mathrm{L}^{-1} \mathrm{GA}_{3}$ and $600 \mathrm{mg} \mathrm{L}^{-1} \mathrm{HA}$ showed values that were not statistically different. The lower concentrations of HA and AA did not show any effect compared to control.

The diameter of the flower shoot was higher in 100 or $150 \mathrm{mg} \mathrm{L}^{-1} \mathrm{GA}_{3}, 600 \mathrm{mg} \mathrm{L}^{-1} \mathrm{HA}$, or $200 \mathrm{mg} \mathrm{L}^{-1}$ AA (Figure 6C). The treatment $50 \mathrm{mg} \mathrm{L}^{-1}$ AA was the only that did not show a significant difference compared to the control.

Shoot moisture content was around $80 \%$ in all treatments. Higher values were observed in 100 or $150 \mathrm{mg} \mathrm{L}^{-1} \mathrm{GA}_{3}$ treatments and $200 \mathrm{mg} \mathrm{L}^{-1} \mathrm{AA}$ treatments (Figure 7A). The root moisture content was mainly affected by the HA treatments that showed the highest values. In particular, higher values were observed at 300 and $600 \mathrm{mg} \mathrm{L}^{-1} \mathrm{HA}$ (Figure 7B). 


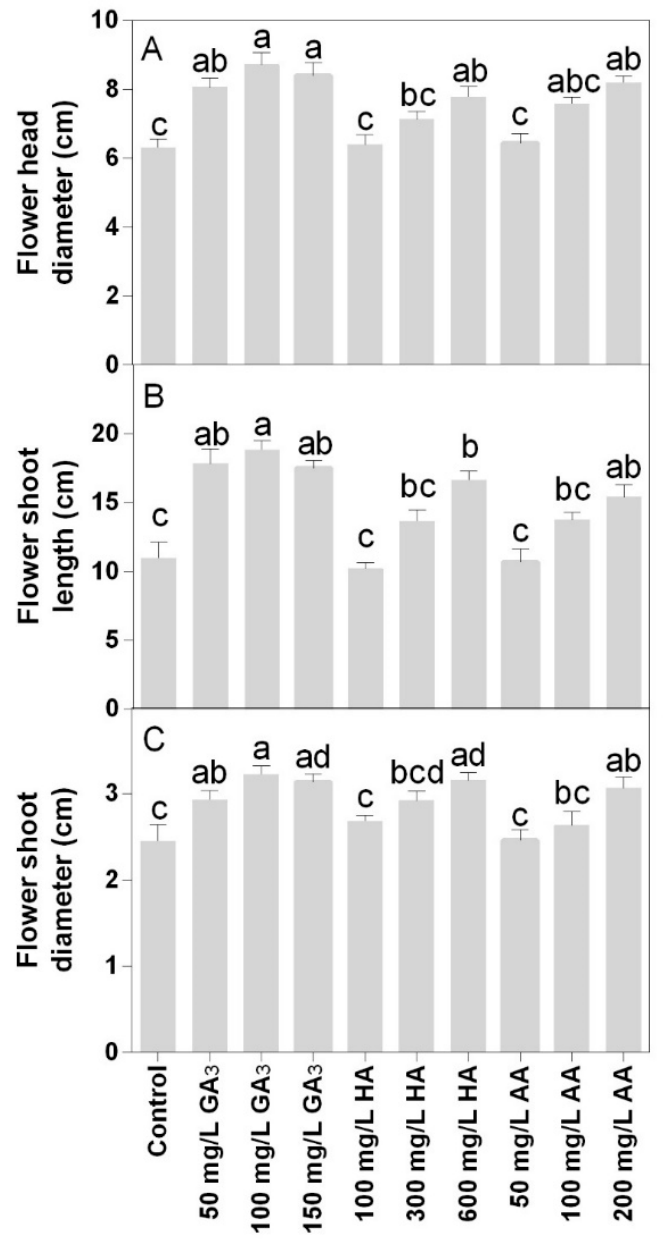

Figure 6. Effect of gibberellic acid (50-100-150 $\mathrm{mg} \mathrm{L}^{-1} \mathrm{GA}$ ), humic acid (100-300-600 mg L $\mathrm{m}^{-1} \mathrm{HA}$ ), and ascorbic acid (50-100-200 $\mathrm{mg} \mathrm{L}^{-1} \mathrm{AA}$ ) foliar applications on the Gazania (A) flower head diameter, (B) flower shoot length and (C) flower shoot diameter. Values are means $\pm \mathrm{SD}(n=15)$. Data were subjected to the Kruskal-Wallis test. Differences among means were determined using Dunn's multiple comparisons test. Significant differences $(P<0.05)$ among bioregulators foliar treatments are indicated by different letters.

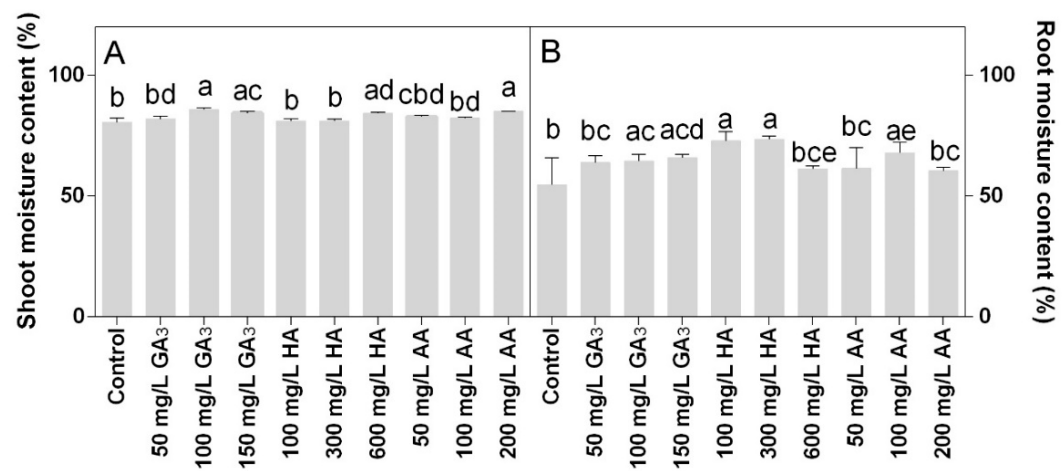

Figure 7. Effect of gibberellic acid (50-100-150 mg/L GA), humic acid (100-300-600 mg/L HA), and ascorbic acid (50-100-200 mg/L AA) foliar applications on the Gazania (A) shoot moisture content and (B) root moisture content. Values are means $\pm \mathrm{SD}(n=15)$. Data were subjected to the Kruskal-Wallis test. Differences among means were determined using Dunn's multiple comparisons test. Significant differences $(P<0.05)$ among bioregulators foliar treatments are indicated by different letters. 


\subsection{The Gas Exchanges Analysis}

The effect of treatments on plant performance was evaluated by monitoring the leaf exchanges. The control plants showed a photosynthetic rate of $9.27 \mu \mathrm{mol} \mathrm{m} \mathrm{m}^{-2} \mathrm{~s}^{-1}$ on average (Table 1). The $\mathrm{GA}_{3}$ treatments induced higher photosynthetic activity with values that ranged from 11.77 to $14.48 \mu \mathrm{mol} \mathrm{m}^{-2} \mathrm{~s}^{-1}$ (Table 1). The 300 and $600 \mathrm{mg} \mathrm{L}^{-1} \mathrm{HA}$ or 100 and $200 \mathrm{mg} \mathrm{L}^{-1}$ AA treatments showed statistically significant higher values compared to the control. The photosynthetic activity in HA treatments was comprised of 9.52 to $12.28 \mu \mathrm{mol} \mathrm{m}^{-2} \mathrm{~s}^{-1}$, while in the AA treatments the range was comprised of 9.81 to $13.11 \mu \mathrm{mol} \mathrm{m}{ }^{-2} \mathrm{~s}^{-1}$.

The transpiration rate in the control plant was $2.68 \mathrm{mmol} \mathrm{m}^{-2} \mathrm{~s}^{-1}$ on average and all treatments showed higher values. The transpiration rate was the highest in the $200 \mathrm{mg} \mathrm{L}^{-1}$ AA treatment with an average of $3.65 \mathrm{mmol} \mathrm{m}^{-2} \mathrm{~s}^{-1}$ (Table 1). The highest stomatal conductance was found in the $100 \mathrm{mg} \mathrm{L}^{-1}$ $\mathrm{GA}_{3}$ treatment with a value of $87 \mathrm{mmol} \mathrm{m} \mathrm{m}^{-2} \mathrm{~s}^{-1}$. Besides $\mathrm{GA}_{3}$ treatments, higher values were also found in the $200 \mathrm{mg} \mathrm{L}^{-1} \mathrm{AA}$ treatment. The WUE calculated for each treatment showed higher values in the 100 and $150 \mathrm{mg} \mathrm{L}^{-1} \mathrm{GA}_{3}$ treatments. The gas exchange data confirmed that $\mathrm{GA}_{3}$ treatments were able to improve the Gazania performance.

Table 1. Effect of exogenous application of bioregulators on physiological attributes of Gazania.

\begin{tabular}{|c|c|c|c|c|}
\hline Treatments & 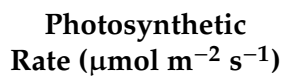 & 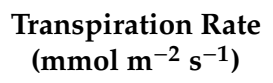 & $\begin{array}{l}\text { Stomatal Conductance } \\
\quad\left(\mathrm{mol} \mathrm{m}^{-2} \mathrm{~s}^{-1}\right)\end{array}$ & $\begin{array}{c}\text { WUE }\left(\mu \mathrm{mol} \mathrm{CO} \mathrm{CO}_{2}\right. \\
\left.\mathrm{mol}^{-1} \mathrm{H}_{2} \mathrm{O}\right)\end{array}$ \\
\hline Control & $9.27 \pm 0.15 c$ & $2.68 \pm 0.11 \mathrm{~d}$ & $0.053 \pm 0.002 \mathrm{f}$ & $172.95 \pm 4.33 \mathrm{~b}$ \\
\hline $\begin{array}{c}\mathrm{GA3} \\
50 \mathrm{mg} \mathrm{L}^{-1}\end{array}$ & $11.77 \pm 0.31 b$ & $3.243 \pm 0.12 b$ & $0.076 \pm 0.002 b c$ & $155.71 \pm 4.39 \mathrm{~cd}$ \\
\hline $\begin{array}{c}\text { GA3 } \\
100 \mathrm{mg} \mathrm{L}^{-1}\end{array}$ & $14.48 \pm 0.19 \mathrm{a}$ & $3.28 \pm 0.05 a b$ & $0.087 \pm 0.003 \mathrm{a}$ & $191.13 \pm 5.35 \mathrm{a}$ \\
\hline $\begin{array}{c}\mathrm{GA3} \\
150 \mathrm{mg} \mathrm{L}^{-1}\end{array}$ & $13.44 \pm 0.22 \mathrm{ab}$ & $3.24 \pm 0.09 \mathrm{~b}$ & $0.083 \pm 0.002 \mathrm{ab}$ & $174.10 \pm 5.01 \mathrm{~b}$ \\
\hline $\begin{array}{c}\mathrm{HA} \\
100 \mathrm{mg} \mathrm{L}^{-1}\end{array}$ & $9.52 \pm 0.31 c$ & $2.81 \pm 0.08 \mathrm{~cd}$ & $0.063 \pm 0.002 \mathrm{e}$ & $157.02 \pm 2.33 \mathrm{~cd}$ \\
\hline $\begin{array}{c}\mathrm{HA} \\
300 \mathrm{mg} \mathrm{L}^{-1}\end{array}$ & $10.91 \pm 0.34 \mathrm{~cd}$ & $3.05 \pm 0.06 \mathrm{bcd}$ & $0.052 \pm 0.003 \mathrm{f}$ & $162.44 \pm 4.14 \mathrm{bcd}$ \\
\hline $\begin{array}{c}\mathrm{HA} \\
600 \mathrm{mg} \mathrm{L}^{-1}\end{array}$ & $12.28 \pm 0.35 \mathrm{abd}$ & $3.27 \pm 0.09 \mathrm{ab}$ & $0.079 \pm 0.002 \mathrm{~b}$ & $164.29 \pm 3.50 \mathrm{bcd}$ \\
\hline $\begin{array}{c}\mathrm{AA} \\
50 \mathrm{mg} \mathrm{L}^{-1}\end{array}$ & $9.81 \pm 0.19 c$ & $2.81 \pm 0.08 \mathrm{~cd}$ & $0.065 \pm 0.002 \mathrm{de}$ & $151.43 \pm 4.87 \mathrm{~d}$ \\
\hline $\begin{array}{c}\mathrm{AA} \\
100 \mathrm{mg} \mathrm{L}^{-1}\end{array}$ & $11.69 \pm 0.24 \mathrm{bd}$ & $3.20 \pm 0.08 b c$ & $0.071 \pm 0.002 \mathrm{~cd}$ & $163.22 \pm 6.10 \mathrm{bcd}$ \\
\hline $\begin{array}{c}\text { AA } \\
200 \mathrm{mg} \mathrm{L}^{-1}\end{array}$ & $13.11 \pm 0.47 \mathrm{ab}$ & $3.65 \pm 0.34 \mathrm{a}$ & $0.083 \pm 0.002 \mathrm{ab}$ & $168.78 \pm 6.67 \mathrm{bc}$ \\
\hline $\begin{array}{c}P>\mathrm{F} \\
\text { (Model) }\end{array}$ & $<0.0001$ & 0.001 & $<0.0001$ & 0.000 \\
\hline Significant & Yes & Yes & Yes & Yes \\
\hline
\end{tabular}

Values are the means of fifteen replicates (plants) $\pm \mathrm{SD}(n=15$. Data were subjected to the Kruskal-Wallis test. Differences among the means were determined using Dunn's multiple comparisons test. Values with different lower-case letters within a column differ significantly at $p \leq 0.05$.

\section{Discussion}

Plant growth regulators (PGRs) are commonly used in agriculture as agronomic tools for modulating crop performance by increasing primary and secondary metabolism. PGRs can promote growth and development, increasing the yield and quality of produce, or and can enhance tolerance against abiotic stresses [33]. Bioregulators include PGRs, as they do not only act on growth, but also on a wide range of plant biological processes.

The concentrations used in this work induced morphological and physiological responses in the treated plants, with positive effects on growth and ornamental quality. 
The gibberellins are plant hormones associated with plant growth and development. There are many gibberellins in plants, but few of them are biologically active and, among them, the most used in horticulture is the $\mathrm{GA}_{3}$. The $\mathrm{GA}_{3}$ or substances with gibberellic-like activities are usually applied to improve germination, promote growth, anticipate flowering, and delay senescence.

In our experiments, the $\mathrm{GA}_{3}$ concentrations used in Gazania seem to have reached the saturation response at $100 \mathrm{mg} \mathrm{L}^{-1}$. In ornamental plants, the exogenous gibberellin applications have been mainly used for flowering induction. $\mathrm{GA}_{3}$ concentrations ranging from 100 to $1500 \mathrm{mg} \mathrm{L}^{-1}$ were effective for flowering stimulation in Philodendron 'Black Cardinal', Dieffenbachia maculata cv. Perfection, and Polianthes tuberose L. cv. Goldorosht Mahallat plants [34-36].

The $\mathrm{GA}_{3}$ applications have been also used for speeding up plant growth and development. The fostering of plant growth has been exploited in the ornamental sector and positive results have been obtained on Polianthes tuberose and snapdragon cut flowers [36,37]. The effect of GA treatments depends on both the species/cultivar and concentrations used [6]. Besides the shoot growth, the $\mathrm{GA}_{3}$ also increased the leaf area and number of leaves in Ficus benjamina, Schefflera arboricola, and Dizigotheeca elegantissima indoor plants [8]. These effects have been also confirmed in our experiments on Gazania rigens. In fact, the $\mathrm{GA}_{3}$ treatment effectively increased leaf and stem length in ornamental plants. The rapid development of plants has been also observed as a positive effect of the $\mathrm{GA}_{3}$ on the photosynthesis activity. In Zantedeschia elliottiana (Watson, England) 'Black Magic' plants treated with $\mathrm{GA}_{3}$ showed a higher content in reducing sugars during the transition to vegetative to flowering stage [38]. Although, the role of $\mathrm{GA}_{3}$ in the sugar metabolism of ornamental plants has not been investigated yet. However, the increase of morpho-anatomic parameters can be associated with the higher photosynthetic activity of plants.

HA can also stimulate plant metabolism, increasing the growth and productivity of crops. HA can be also classified as a plant biostimulant and has effects on the nutrients use efficiency or enhancement of tolerance against abiotic stresses [39]. In our experiments, HA and concentrations used showed a dose-response effect. Results obtained suggest that higher concentrations could be explored. In ornamental plants, in marigold applications of HA with concentrations ranging from 2500 to $5000 \mathrm{mg} \mathrm{L}^{-1}$ had positive effects on the increase of root biomass, number, and length of roots, as well as on stem length, flower, and leaf number [40,41]. In our experiments, the HA treatments were less effective than $\mathrm{GA}_{3}$, but were able to induce positive and significant results. The concentrations used were lower than those reported in the literature, demonstrating that the efficacy of HA can be also exploited at lower concentrations. The positive effect of HA on plant growth has been associated with the proprieties of hormone-like activities [42]. In particular, humic substances obtained from the feces of the earthworm were able to induce auxin-like responses in plants [43]. Since auxins are plant hormones that stimulate root initiation and development [33], these findings explain the effects of 100 and $300 \mathrm{mg} \mathrm{L}^{-1} \mathrm{HA}$ treatments on root biomass stimulation observed in treated Gazania plants.

The AA is an antioxidant molecule that plays an important role in the regulation of stressful conditions in plants $[44,45]$. The AA is an antioxidant with the ability to donate electrons in several non-enzymatic and enzymatic reactions. It plays an important role in many physiological and biochemical processes in plants such as growth, differentiation, and metabolism. The concentration of AA especially increases during stress conditions and its main function is as a scavenger of reactive oxygen species (ROS). The action of AA is involved in the detoxification of hydrogen peroxide and is part of the ascorbate-glutathione cycle [45]. The supply of AA exogenously can increase the tolerance of plants to stress conditions and avoids the ROS accumulation. This hypothesis may explain the positive results obtained from our experiments.

The AA was particularly efficient in the stimulation flower production. This effect could be explained, considering the antioxidant effect of the AA and the interconnection with primary metabolism. In fact, $200 \mathrm{mg} \mathrm{L}^{-1}$ AA showed a photosynthetic rate was among the higher if compared with other treatments. In plants, exogenously applications of AA in tomato increased the recovery of seedlings after salinity stress [45]. Analogous results were obtained in maize plants that showed 
higher tolerance to cadmium exposure [46]. In ornamental plants, treatments of AA had a positive effect on Codiaeum variegatum L. [47], plant growth with analogous results to those observed in Gazania. The beneficial effect of the AA treatments can be observed in the inhibition of lipid peroxidation and maintenance of the cell membrane functionality. All treatments were able to improve the leaf gas exchanges with significant effects, depending on the treatments and concentrations applied. The positive effects can be due to direct and indirect actions of treatments. The $\mathrm{GA}_{3}$ and HA could have direct effect on plant growth by increasing the primary and secondary metabolism and showed higher and significant effects compared to the control. AA instead might have had an indirect effect on plant growth and development by increasing the plant tolerance to the stressful conditions and reducing the oxidative stress in the treated plants.

Results suggest that Gazania plant production can be effectively improved with the bioregulators used here. The positive effects should also be evaluated under abiotic stresses and the ability of these treatments to counteract different abiotic stresses that can occur during plant cultivation should be evaluated.

Further investigations should be carried out for HA and AA treatments and, in particular, higher concentrations should be considered, because the results indicated that the saturation of the response was not reached at the higher concentration. However, a cost-benefit evaluation should be also taken into consideration in order to identify which treatment and concentration combination provides the highest remuneration.

\section{Conclusions}

In conclusion, all bioregulators tested can be suggested for improving the performance of Gazania plants, in terms of plant growth, flower production, and longevity. Among them, the $\mathrm{GA}_{3} 100 \mathrm{mg} \mathrm{L}^{-1}$ was the treatment that showed the best results and could be suggested as the treatment for reducing the crop cycle and improving the ornamental value of the plants. The $\mathrm{GA}_{3}$ application can also be suggested under limited water availability, considering the higher WUE observed. However, the HA and AA could be also used, and their choice could be done considering their costs and hence the economic sustainability in the production system.

Author Contributions: Conceptualization, F.Z.; methodology, A.Y. and F.Z.; software, validation, formal analysis, F.Z., A.F. (Antonio Ferrante); writing—original draft preparation, F.Z.; writing-review and editing, F.Z., A.Y., Z.A., A.F. (Alessandra Francini), and A.F. (Antonio Ferrante).

Funding: This research received no external funding.

Conflicts of Interest: The authors declare no conflict of interest.

\section{References}

1. Zulfiqar, F.; Casadesús, A.; Brockman, H.; Munné-Bosch, S. An overview of plant-based natural biostimulants for sustainable horticulture with a particular focus on moringa leaf extracts. Plant Sci. 2019, 110194. [CrossRef]

2. García-Caparrós, P.; Lao, M.T. The effects of salt stress on ornamental plants and integrative cultivation practices. Sci. Hortic. 2018, 240, 430-439. [CrossRef]

3. Younis, A.; Riaz, A.; Qasim, M.; Mansoor, F.; Zulfiqar, F.; Tariq, U.; Ahsan, M.; Naseem, M.K.; Bhatti, Z.M. Screening of marigold (Tagetes erecta L.) cultivars for drought stress based on vegetative and physiological characteristics. Int. J. Food Allied Sci. 2018, 3, 56. [CrossRef]

4. Younis, A.; Akhtar, M.S.; Riaz, A.; Zulfiqar, F.; Qasim, M.; Farooq, A.; Tariq, U.; Ahsan, M.; Bhatti, Z.M. Improved cut flower and corm production by exogenous moringa leaf extract application on gladiolus cultivars. Acta Sci. Pol. Hortorum Cultus 2018, 17, 25-38. [CrossRef]

5. Sajjad, Y.; Jaskani, M.J.; Asif, M.; Qasim, M. Application of plant growth regulators in ornamental plants: A review. Pak. J. Agric. Sci. 2017, 54,327-333.

6. Mills-Ibibofori, T.; Dunn, B.L.; Maness, N.; Payton, M. Effect of LED Lighting and Gibberellic Acid Supplementation on Potted Ornamentals. Horticulturae 2019, 5, 51. [CrossRef] 
7. Rademacher, W. Plant Growth Regulators: Backgrounds and Uses in Plant Production. J. Plant Growth Regul. 2015, 34, 845-872. [CrossRef]

8. Sardoei, A.S. Plant growth regulators effects on the growth and photosynthetic pigments on three indoor ornamental plants. Eur. J. Exp. Biol. 2014, 4, 311-318.

9. Camara, M.C.; Vandenberghe, L.P.S.; Rodrigues, C.; de Oliveira, J.; Faulds, C.; Bertrand, E.; Soccol, C.R. Current advances in gibberellic acid $\left(\mathrm{GA}_{3}\right)$ production, patented technologies and potential applications. Planta 2018, 248, 1049-1062. [CrossRef]

10. Chen, S.Y.; Kuo, S.R.; Chien, C.T. Roles of gibberellins and abscisic acid in dormancy and germination of red bayberry (Myrica rubra) seeds. Tree Physiol. 2008, 28, 1431-1439. [CrossRef] [PubMed]

11. Urbanova, T.; Leubner-Metzger, G. Gibberellins and seed germination. In Annual Plant Reviews; John Wiley \& Sons, Ltd.: Hoboken, NJ, USA, 2016; Volume 49, pp. 253-284.

12. Sajid, M.; Amin, N.; Ahmad, H.; Khan, K. Effect of gibberellic acid on enhancing flowering time in Chrysanthemum morifolium. Pak. J. Bot. 2016, 48, 477-483.

13. Dong, B.; Deng, Y.; Wang, H.; Gao, R.; Stephen, G.K.; Chen, S.; Jiang, J.; Chen, F. Gibberellic Acid Signaling Is Required to Induce Flowering of Chrysanthemums Grown under Both Short and Long Days. Int. J. Mol. Sci. 2017, 18, 1259. [CrossRef] [PubMed]

14. Hedden, P. Gibberellin biosynthesis in higher plants. In Annual Plant Reviews; John Wiley \& Sons, Ltd.: Hoboken, NJ, USA, 2016; Volume 49, pp. 37-72.

15. Xue, J.; Li, T.; Wang, S.; Xue, Y.; Hu, F.; Zhang, X. Elucidation of the mechanism of reflowering in tree peony (Paeonia suffruticosa) 'Zi Luo Lan' by defoliation and gibberellic acid application. Plant Physiol. Biochem. 2018, 132, 571-578. [CrossRef] [PubMed]

16. Bergmann, B.A.; Dole, J.M.; McCall, I. Gibberellic acid shows promise for promoting flower stem length in four field-grown cut flowers. HortTechnology 2016, 26, 287-292. [CrossRef]

17. Ferrante, A.; Mensuali-Sodi, A.; Serra, G. Effect of thidiazuron and gibberellic acid on leaf yellowing of cut stock flowers. Cent. Eur. J. Biol. 2009, 4, 461-468. [CrossRef]

18. Imsabai, W.; van Doorn, W.G. Effects of auxin, gibberellin, and cytokinin on petal blackening and flower opening in cut lotus flowers (Nelumbo nucifera). Postharvest Biol. Technol. 2013, 75, 54-57. [CrossRef]

19. Do Nascimento Simões, A.; Diniz, N.B.; da Silva Vieira, M.R.; Ferreira-Silva, S.L.; da Silva, M.B.; Minatel, I.O.; Lima, G.P.P. Impact of $\mathrm{GA}_{3}$ and spermine on postharvest quality of anthurium cut flowers (Anthurium andraeanum) cv. Arizona. Sci. Hortic. 2018, 241, 178-186. [CrossRef]

20. Van Oosten, M.J.; Pepe, O.; De Pascale, S.; Silletti, S.; Maggio, A. The role of biostimulants and bioeffectors as alleviators of abiotic stress in crop plants. Chem. Biol. Technol. Agric. 2017, 4, 5. [CrossRef]

21. Nardi, S.; Ertani, A.; Francioso, O. Soil-root cross-talking: The role of humic substances. J. Plant Nutr. Soil Sci. 2017, 180, 5-13. [CrossRef]

22. Popescu, G.C.; Popescu, M. Yield, berry quality and physiological response of grapevine to foliar humic acid application. Bragantia 2018, 77, 273-282. [CrossRef]

23. Canellas, L.P.; Olivares, F.L.; Aguiar, N.O.; Jones, D.L.; Nebbioso, A.; Mazzei, P.; Piccolo, A. Humic and fulvic acids as biostimulants in horticulture. Sci. Hortic. 2015, 196, 15-27. [CrossRef]

24. Elmongy, M.S.; Zhou, H.; Cao, Y.; Liu, B.; Xia, Y. The effect of humic acid on endogenous hormone levels and antioxidant enzyme activity during in vitro rooting of evergreen azalea. Sci. Hortic. 2018, 227, $234-243$. [CrossRef]

25. De Pascale, S.; Rouphael, Y.; Colla, G. Plant biostimulants: Innovative tool for enhancing plant nutrition in organic farming. Eur. J. Hortic. Sci. 2018, 82, 277-285. [CrossRef]

26. Cordeiro, F.C.; Santa-Catarina, C.; Silveira, V.; de SOUZA, S.R. Humic acid effect on catalase activity and the generation of reactive oxygen species in corn (Zea mays). Biosci. Biotechnol. Biochem. 2011, 75, 70-74. [CrossRef]

27. Soppelsa, S.; Kelderer, M.; Casera, C.; Bassi, M.; Robatscher, P.; Andreotti, C. Use of biostimulants for organic apple production: Effects on tree growth, yield performances and fruit quality at harvest and during storage. Front. Plant Sci. 2018, 9, 1342. [CrossRef]

28. Olivares, F.L.; Aguiar, N.O.; Rosa, R.C.C.; Canellas, L.P. Substrate biofortification in combination with foliar sprays of plant growth promoting bacteria and humic substances boosts production of organic tomatoes. Sci. Hortic. 2015, 183, 100-108. [CrossRef] 
29. Rose, M.T.; Patti, A.F.; Little, K.R.; Brown, A.L.; Jackson, W.R.; Cavagnaro, T.R. A Meta-Analysis and Review of Plant-Growth Response to Humic Substances. In Advances in Agronomy; Academic Press: Cambridge, MA, USA, 2014; pp. 37-89.

30. Debolt, S.; Melino, V.; Ford, C.M. Ascorbate as a biosynthetic precursor in plants. Ann. Bot. 2007, 99, 3-8. [CrossRef]

31. Horemans, N.; Potters, G.; De Wilde, L.; Caubergs, R.J. Division of tobacco bright yellow-2 cell cultures. Plant Physiol. 2003, 133, 361-367. [CrossRef]

32. Akram, N.A.; Shafiq, F.; Ashraf, M. Ascorbic acid-a potential oxidant scavenger and its role in plant development and abiotic stress tolerance. Front. Plant Sci. 2017, 8, 613. [CrossRef]

33. Davies, P.J. Plant Hormones: Physiology, Biochemistry and Molecular Biology; Springer Science \& Business Media: Berlin, Germany, 2013.

34. Henny, R.J. Gibberellic acid $\left(\mathrm{GA}_{3}\right)$ induces flowering in Dieffenbachia maculate 'Perfection'. HortScience 1980, 15, 613.

35. Chen, J.; Henny, R.J.; McConnell, D.B.; Caldwell, R.D. Gibberellic acid affects growth and flowering of Philodendron 'Black Cardinal'. Plant Growth. Regul. 2003, 41, 1-6. [CrossRef]

36. Asil, M.H.; Roein, Z.; Abbasi, J. Response of tuberose (Polianthes tuberose L.) to gibberellic acid and benzyladenine. Hortic. Environ. Biotechnol. 2011, 52, 46. [CrossRef]

37. Malik, S.N.; Qadri, Z.A.; Nazki, I.; Mir, S.; Khan, F.A.; Pukhta, M.S. Effect of Gibberellic Acid, Spacing and Nutrient Sprays on Growth and Flowering in Snapdragon (Antirrhinum majus L.) cv. Rocket Pink. Int. J. Plant Soil Sci. 2019, 28, 1-6. [CrossRef]

38. Kozłowska, M.; Rybus-Zając, M.; Stachowiak, J.; Janowska, B. Changes in carbohydrate contents of Zantedeschia leaves under gibberellin-stimulated flowering. Acta Physiol. Plant. 2007, 29, 27-32. [CrossRef]

39. Bulgari, R.; Franzoni, G.; Ferrante, A. Biostimulants Application in Horticultural Crops under Abiotic Stress Conditions. Agronomy 2019, 9, 306. [CrossRef]

40. Evans, M.R.; Li, G. Effect of humic acids on growth of annual ornamental seedling plugs. HortTechnology 2003, 13, 661-665. [CrossRef]

41. Mohammadipour, E.; Golchin, A.; Mohammadi, J.; Negahdar, N.; Zarchini, M. Effect of humic acid on yield and quality of marigold (Calendula officinalis L.). Ann. Biol. Res. 2012, 3, 5095-5098.

42. Nardi, S.; Arnoldim, G.; Dell'Agnola, G. Release of the hormone-like activities from Allolobophora rosea (Sav.) and Allolobophora caliginosa (Sav.) feces. Can. J. Soil Sci. 1988, 68, 563-567. [CrossRef]

43. Muscolo, A.; Bovalo, F.; Gionfriddo, F.; Nardi, S. Earthworm humic matter produces auxin-like effects on Daucus carota cell growth and nitrate metabolism. Soil Biol. Biochem. 1999, 31, 1303-1311. [CrossRef]

44. Smirnoff, N. Ascorbic acid: Metabolism and functions of a multi-facetted molecule. Curr. Opin. Plant Biol. 2000, 3, 229-235. [CrossRef]

45. Shalata, A.; Neumann, P.M. Exogenous ascorbic acid (vitamin C) increases resistance to salt stress and reduces lipid peroxidation. J. Exp. Bot. 2001, 52, 2207-2211. [CrossRef] [PubMed]

46. Zhang, K.; Wang, G.; Bao, M.; Wang, L.; Xie, X. Exogenous application of ascorbic acid mitigates cadmium toxicity and uptake in Maize (Zea mays L.). Environ. Sci. Pollut. Res. 2019, 26, 19261-19271. [CrossRef] [PubMed]

47. Mazher, A.A.; Zaghloul, S.M.; Mahmoud, S.A.; Siam, H.S. Stimulatory effect of kinetin, ascorbic acid and glutamic acid on growth and chemical constituents of Codiaeum variegatum L. plants. Armerican-Eurasian J. Agric. Environ. Sci. 2011, 10, 318-323.

(C) 2019 by the authors. Licensee MDPI, Basel, Switzerland. This article is an open access article distributed under the terms and conditions of the Creative Commons Attribution (CC BY) license (http://creativecommons.org/licenses/by/4.0/). 